\title{
Aspek Hukum Laboratorium Forensik Keimigrasian: Studi Kasus Pemeriksaan Paspor Palsu Kebangsaan Inggris Atas Nama Abbas Tauqeer
}

\section{Alvi Syahrin}

Pejabat Imigrasi, Direktorat Jenderal Imigrasi

Dosen Tetap Program Studi Hukum Keimigrasian, Politeknik Imigrasi

ma.syahrin@gmail.com

\begin{abstract}
Increased traffic flow of people entering and leaving Indonesia, had causing various level of immigration crimes. Passport fraud as a crime committed by replacing, altering part or all of a passport, or using false information to receive a passport, has become a serious matter now. Currently, almost all the proof of counterfeit passport process is checked in the Immigration Forensic Laboratory at the Immigration Intelligence Directorate. The formulation of the problem studied in this paper is how the role and challenge of Immigration Forensic Laboratory in conducting examination of fake passport on behalf of Abbas Tauqeer.

The research method used is normative and empirical legal research. Based on the results of the research can be seen that the Immigration Forensic Laboratory has an important role as the center of examination of fake immigration documents consisting of several technical stages. Forensic analysis of the case found damage to passport biodata pages, different types of letters on passport biography, photos and biodata replaced, passport chips damaged, and unreadable chips in Automatic Document Reader. Then, the challenges faced include the lack of human resources, facilities and infrastructure has not been representative, the absence of Standard Operational Procedure (SOP), and the lack of care of officers in the field.
\end{abstract}

Keywords: Immigration Forensic Laboratory, Counterfeit Passport

\section{PENDAHULUAN}

\section{Latar Belakang}

Hadirnya globalisasi telah memudahkan setiap orang untuk melakukan perjalanan dari suatu negara ke negara lain. Kebebasan pergerakan manusia untuk berpindah antar negara merupakan suatu hak dasar atau asasi manusia yang dijamin dalam konstitusi. Hak bermigrasi ini diatur dalam Pasal 28E UUD 1945 (Amandemen), yang menentukan bahwa: "Setiap warga 
negara bebas untuk .... memilih tempat tinggal di wilayah negara dan meninggalkannya, serta berhak kembali."1

Namun untuk tertib hukum agar tidak melanggar hak orang lain, kebebasan tersebut perlu dilakukan pengaturan melalui pelbagai peraturan perundang-undangan tentang bagaimana caranya, prosedur serta persyaratan yang diperlukan. Oleh karena itu, negara perlu hadir untuk menjawab persoalan itu semua. ${ }^{2}$ Keadaan ini harus dipandang sebagai hal yang wajar tanpa menghilangkan kewaspadaan karena tanpa disadari pasti akan membawa dampak permasalahan terutama pada lalu lintas antar negara. Hal ini dapat dimaklumi, karena harus diakui dengan adanya migrasi internasional ${ }^{3}$ ini sedikit banyak akan membawa pengaruh baik dan buruk bagi negara tujuan.

1 M. Alvi Syahrin, Hak Asasi Bermigrasi, Majalah Bhumi Pura, November 2015, Jakarta Direktorat Jenderal Imigrasi, hlm. 45-48. Dalam sistem hukum Indonesia, hak berpindah (bemigrasi) ini diatur dalam Pasal 2 UU No. 6 Tahun 2011 tentang Keimigrasian disebutkan: "Setiap warga negara Indonesia berhak melakukan perjalanan masuk dan keluar wilayah Indonesia". Sehingga dapat dipahami, kebebasan untuk bergerak melintas atau berpindah antar negara (hak berimigrasi) merupakan hak asasi manusia yang mendasar.

Periksa juga http://muhammadalvisyahrin.blogspot.co.id/2014/11/imigran-ilegal-danham-universal.html, diakses pada hari Sabtu (30/01/2016), pukul 15.54 WIB. Batasan dan pembagian bidang, jenis, dan macam HAM dunia mencakup enam kelompok. Pertama, hak asasi pribadi (personal rights). Termasuk di dalamnya adalah hak kebebasan untuk bergerak, hak berpergian dan berpindah-pindah tempat (hak bermigrasi), hak kebebasan mengeluarkan atau menyatakan pendapat, hak kebebasan memilih dan aktif di organisasi atau perkumpulan, serta hak kebebasan untuk memilih, memeluk, dan menjalankan agama dan kepercayaan yang diyakini masing-masing.

Bandingkan dengan M. Arif Nasution, 1999, Globalisasi dan Migrasi Antar Negara, Bandung: Penerbit Alumni, hlm. 11.

Lihat juga, M. Iman Santoso, 2014, Perspektif Imigrasi dalam Migrasi Manusia, Bandung: Pustaka Reka Cipta, hlm. 1-3.

2 M. Alvi Syahrin, Loc. cit., Hak berpindah tidak dapat dilaksanakan secara frontal. Hak tersebut berkaitan dengan kedaulatan dan hukum yang mengikat dari suatu negara. Setiap negara memiliki standar hukum yang berbeda untuk melindungi kepentingannya.

${ }^{3}$ M. Alvi Syahrin, Imigran Ilegal, Migrasi atau Ekspansi?, Majalah Check Point, Edisi 3, Oktober 2015, Jakarta: Akademi Imigrasi, hlm. 29-31. Lihat juga, Chotib, Migrasi: Kajian Kependudukan dan Ketenagakerjaan, Program Pascasarjana Universitas Indonesia, hlm. 68.

Migrasi adalah perpindahan penduduk dengan tujuan untuk menetap dari suatu tempat ke tempat lain melewati batas administratif (migrasi internal) atau batas politik/negara (migrasi internasional). Dengan kata lain, migrasi diartikan sebagai perpindahan yang relatif permanen dari suatu daerah (negara) ke daerah (negara) lain. Ada dua dimensi penting dalam penelaahan migrasi, yaitu dimensi ruang/daerah (spasial/locus) dan dimensi waktu (tempus).

Jenis-jenis migrasi mencakup dua bidang. Pertama, migrasi internasional, yaitu perpindahan penduduk dari suatu negara ke negara lain. Migrasi ini lazim dilakukan oleh para pengungsi dan para pencari suaka internasional yang melewati dan menduduki suatu negara tertentu. Kedua, migrasi internal, yaitu perpindahan yang terjadi dalam satu negara, misalnya antar provinsi, antar kota/kabupaten, migrasi perdesaan ke perkotaaan atau suatu administratif lainnya yang lebih rendah daripada tingkat kabupaten, seperti kecamatan, kelurahan, dan seterusnya. Jenis migrasi ini terjadi antar unit administratif dalam satu negara. Seseorang dikatakan migran, jika dia tinggal di tempat yang baru atau berniat tinggal di tempat yang bari itu paling lama enam bulan lamanya. 
Dalam Undang-Undang Nomor 6 Tahun 2011 tentang Keimigrasian (selanjutnya disebut UU No. 6 Tahun 2011) menjelaskan setiap orang yang masuk atau keluar Wilayah Indonesia harus memiliki dokumen perjalanan, yaitu dokumen resmi yang dikeluarkan oleh pejabat yang berwenang dari suatu negara yang memuat identitas pemegangnya dan berlaku untuk melakukan perjalanan antar negara. ${ }^{4}$ Tanpa memiliki surat perjalanan (paspor) yang sah dan masih berlaku, tidak seorang pun dapat diizinkan masuk atau keluar Wilayah Indonesia. Namun hal ini tidak menutup kemungkinan terdapat pihak yang memiliki kepentingan tertentu untuk melakukan kejahatan pemalsuan paspor.

Pemalsuan paspor adalah kejahatan yang dilakukan dengan cara mengganti, mengubah sebagian atau secara keseluruhan dari sebuah paspor atau menggunakan informasi palsu untuk menerima paspor. Kejahatan ini sering digunakan untuk mendapatkan izin masuk secara ilegal ke suatu negara, dan juga terkait dengan kejahatan internasional seperti perdagangan narkoba dan terorisme. ${ }^{5}$

Banyak negara yang memiliki hukuman sangat ketat untuk siapa pun yang didakwa memalsukan paspor, dengan hukuman penjara dalam waktu yang lama atau deportasi. Ada banyak alasan yang berbeda seseorang melakukan pemalsuan paspor. Beberapa paspor digunakan untuk memasuki sebuah negara secara ilegal untuk bekerja atau bertempat tinggal. Mereka menghindari aparat penegak hukum dan deteksi agar dapat menggunakan paspor palsu saat bepergian.

Paspor palsu atau dokumen yang diperoleh secara ilegal juga digunakan oleh orang yang mencoba untuk masuk ke suatu negara untuk tujuan kejahatan yang dilakukannya, seperti tindakan teroris atau penyelundupan narkoba. Penipuan jenis ini dapat dilakukan dalam berbagai cara yang berbeda. Seseorang mungkin mencuri atau membeli blanko paspor asli dan kemudian mengubah foto, informasi identitas, dan masa habis berlakunya agar sesuai dengan tujuan mereka. Beberapa modus pemalsuan dengan menciptakan paspor yang sepenuhnya palsu, meskipun ini mungkin lebih mudah untuk diungkap karena mereka biasanya tidak akan menerakkan watermark atau fitur-fitur keamanan yang terdapat dalam paspor asli. ${ }^{6}$ Terkadang, seseorang mendapatkan paspor asli dengan menyerahkan

4 Baca Indonesia. Undang-Undang tentang Keimigrasian. UU No. 6 Tahun 2011. LN Tahun 2011 Nomor 52, Pasal 8.

${ }^{5}$ M. Alvi Syahrin, Reorientasi Fungsi Imigrasi Indonesia: Kembalikan ke Fitrah Penjaga Gerbang Negara, Majalah Bhumi Pura, September 2015, Jakarta: Direktorat Jenderal Imigrasi, hlm. 36-40.

6 Prenardi Herdiyana, 2013, Peranan Laboratorium Forensik Keimigrasian Direktorat Jenderal Imigrasi Dalam Pemeriksaan Dokumen Keimigrasian Palsu, Kertas Kerja Perorangan, Badan Pengembangan Sumber Daya Manusia Hukum dan HAM RI, Akademi Imigrasi, hlm. 2; Lihat juga Anonim, Pemeriksaan Dokumen Modern, Direktorat Intelijen Keimigrasian, hlm. 31. Bandingkan dengan, Bandingkan, M. Iman Santoso, Perpektif 2007, Imigrasi dalam United Nation Convention Against Transnational Organized Crime, Cet-1, Jakarta: Perum Percetakan Negara RI. 
dokumen-dokumen yang dipalsukan dalam proses aplikasi, seperti KTP, akte kelahiran atau identitas palsu lainnya.

Hukuman bagi penipuan paspor berbeda disetiap negara, di Amerika Serikat menurut U.S. Department of State, pemalsuan paspor dan visa adalah tindakan kriminal yang dapat dihukum sampai 10 tahun penjara dan denda sebesar \$250.000. Hukuman penjara maksimum dapat menjadi 15 tahun jika pelanggaran terhubung ke perdagangan narkoba, dan 20 tahun jika dihubungkan dengan terorisme. Di Australia, hukuman termasuk sepuluh tahun penjara dan denda sampai \$ 170.000 dolar Australia (Australia Government Department of Foreign Affairs and Trade). Sedangkan di Indonesia ancaman hukuman bagi pelaku pemalsuan paspor diatur dalam Pasal 126, 127 dan 129 Undang-undang No. 6 Tahun 2011 tentang Keimigrasian, dengan ancaman hukuman penjara paling lama 5 tahun dan denda paling banyak Rp. 500.000.000,00 (lima ratus juta rupiah). ${ }^{7}$

Meskipun biaya penipuan biasanya dibebankan kepada orang yang menggunakan paspor palsu, namun siapa pun yang terlibat dalam proses pembuatan atau memperoleh paspor palsu dapat bertanggung jawab atas tindakan kriminal. Setiap orang yang membuat paspor palsu, menjual paspor curian atau paspor yang telah habis masa berlakunya, atau membantu orang asing ilegal dalam mendapatkan paspor palsu dan visa juga dapat dikenakan hukuman. Karena pemalsuan paspor dianggap ancaman besar bagi keamanan nasional, membantu dan bersekongkol merupakan kejahatan yang harus dikenai hukuman berat.

Dalam Pasal 8 ayat (1) UU No. 6 Tahun 2011 menyebutkan, "Setiap orang yang masuk atau keluar Wilayah Indonesia wajib memiliki Dokumen Perjalanan yang sah dan masih berlaku.". Hal ini perlu dilakukan pengawasan pada tempat perlintasan antar negara yang merupakan kewenangan dari Direktorat Jenderal Imigrasi. Dalam proses pengawasan di Tempat Pemeriksaan Imigrasi (TPI), pejabat imigrasi berwenang melakukan pemeriksaan pada paspor. Pemeriksaan paspor palsu tidak hanya dilakukan di TPI saja, tetapi juga dilakukan di Kantor Imigrasi. Proses pemeriksaan yang dilakukan secara manual menggunakan peralatan biasa dapat mengidentifikasikan sebuah paspor palsu atau tidak. Namun untuk pembuktiannya, diperlukan metode forensik dokumen yang dapat secara rinci mengungkapkan dengan jelas hasil identifikasi paspor palsu atau tidak. ${ }^{8}$

Oleh sebab itu, pada tahun 2003 dibentuklah Laboratorium Forensik Keimigrasian hasil kerja sama antara pemerintah Indonesia yang diwakili oleh Direktorat Jenderal Imigrasi dengan pemerintah Australia yang diwakili oleh DIMIA (Department of Immigration, Indigenous and Multicultural

7 Ibid.

8 Syahrin, M.A., 2017. The Implementation of Non-Refoulement Principle to the Asylum Seekers and Refugees in Indonesia. Sriwijaya Law Review, 1(2), pp.168-178. Lihat juga, Fernando, S., 2014. Politik Hukum Pemerintah (Direktorat Jenderal Imigrasi) Dalam Menanggulangi Masalah Penyelundupan Manusia. Kumpulan Jurnal Mahasiswa Fakultas Hukum, 1(1). 
Affairs). Pada awalnya berdasarkan Keputusan Menteri Kehakiman RI Nomor: M.04.PR.07.10 tahun 2004 tentang Organisasi Tata Kerja Departemen Kehakiman dan Hak Asasi Manusia, Laboratorium Forensik Keimigrasian berada dibawah Direktorat Penindakan Keimigrasian dan Rumah Detensi.

Kemudian, karena berperan sebagai bagian dari sistem pencegahan dan pengembangan penyelidikan dan pengumpulan bahan informasi dalam mengambil tindakan hukum, maka sesuai Keputusan Menteri Hukum dan Hak Asasi Manusia RI Nomor: M.03-PR.07.10 tahun 2005 tanggal 7 Desember, Laboratorium Forensik Keimigrasian ditempatkan pada Direktorat Intelijen Keimigrasian dibawah Sub Direktorat Produksi Intelijen Keimigrasian.

Sejak berdiri sekitar dua belas tahun yang lalu, Laboratorium Forensik Keimigrasian memiliki peran untuk turut serta dalam menjaga keamanan dan kepentingan negara dari orang-orang yang masuk atau keluar wilayah Indonesia, baik yang membahayakan atau tidak memberikan manfaat bagi pembangunan negara. Diperlukan penguatan sebuah rancangan kerja dan manajemen pengelolaan secara profesional dan sistematis, sehingga Laboratorium Forensik Keimigrasian dapat secara maksimal menjadi salah satu bagian terpenting bagi keberhasilan tujuan institusi Imigrasi Indonesia.

Adapun tugas Laboratorium Forensik Keimigrasian sesuai dengan Pasal 624 ayat (3) Peraturan Menteri Hukum dan Hak Asasi Manusia RI Nomor 29 Tahun 2015 tentang Organisasi Tata Kerja Kementerian Hukum dan Hak Asasi Manusia adalah melakukan penyiapan bahan perumusan dan koordinasi kebijakan, bimbingan teknis, supervisi serta pelaksanaan kebijakan di bidang pendeteksian dokumen keimigrasian, pengumpulan, dan pemeliharaan dan pengelolaan perangkat laboratorium forensik.

Saat ini, hampir semua proses pembuktian paspor palsu dilakukan di Laboratorium Forensik Keimigrasian pada Direktorat Intelijen Keimigrasian. Hal ini terjadi dikarenakan tidak semua Tempat Pemeriksaan Imigrasi dan Kantor Imigrasi memiliki sarana Laboratorium Forensik yang memadai dan minimnya ilmu pengetahuan forensik dokumen bagi petugas.

Kasus yang saat ini sedang ditangani oleh Laboratorium Forensik Keimigrasian Direktorat Intelijen Keimigrasian adalah pemalsuan paspor kebangsaan Inggris atas nama Abbas Tauqeer. Kasus ini mendapat perhatian serius dari Direktorat Jenderal Imigrasi, Kedutaan Besar Inggris, dan Perwakilan Negara Pakisan di Indonesia. ${ }^{9}$

Abbas Tauqeer merupakan warga negara Pakistan yang diduga telah menggunakan paspor kebangsaan Inggris yang telah dipalsukan untuk masuk ke Wilayah Indonesia. Ia menggunakan paspor palsu tersebut untuk berlibur di Bali. Setelah dilakukan proses interogasi secara mendalam oleh Pejabat Imigrasi di Tempat Pemeriksaan Imigrasi Bandar Udara Ngurah Rai, maka Abbas Tauqeer segera diamankan untuk dilakukan penyidikan.

\footnotetext{
${ }^{9}$ Berita Acara Interogasi Tauqeer Abbas, dilaksanakan pada hari Minggu (02/08/2015), pukul 14.00 WITA, bertempat di Kantor Imigrasi Kelas I Khusus Ngurah Rai.
} 
Kemudian, paspor yang diduga palsu tersebut diserahkan kepada Laboratorium Forensik Keimigrasian yang bertempat di Direktorat Intelijen Keimigrasian untuk dilakukan pemeriksaan forensik secara ilmiah. ${ }^{10}$

\section{Rumusan Masalah}

Berdasarkan uraian di atas, maka permasalahan yang akan dibahas dalam tulisan ini adalah:

1. Bagaimana peranan Laboratorium Forensik Keimigrasian dalam melakukan pemeriksaan paspor palsu kebangsaan Inggris atas nama Abbas Tauqeer?

2. Apa tantangan yang dihadapi Laboratorium Forensik Keimigrasian dalam melakukan pemeriksaan paspor palsu kebangsaan Inggris atas nama Abbas Tauqeer?

\section{Metode Penelitian}

\section{Pendekatan}

Jenis pendekatan yang digunakan adalah penelitian hukum normatif dan empiris. Maksudnya adalah penelitian yang menggambarkan, menjelaskan, menganalisis, serta mengembangkan dengan dilengkapi data lapangan yang terkait dengan isu hukum terkait. ${ }^{11}$

\section{Metode Pengumpulan Data}

Pengumpulan bahan-bahan hukum dilakukan dengan mengidentikasi dan menginventarisasi peraturan perundang-undangan, meneliti bahan pustaka (tulisan dan hasil karya ilmiah), dan sumber-sumber lain seperti wawancara yang ada relevansinya dengan isu hukum dalam penelitian ini.

\section{Teknik Analisa Data}

Teknik analisa isu hukum (legal issue) dalam penelitian ini menggunakan logika berpikir campuran. Maksudnya penalaran (hukum) yang merupakan gabungan dari pola berpikir induktif (inductive) dan deduktf (deductive) dalam persoalan hukum faktual yang konkrit. Proses yang terjadi dalam logika berpikir campuran adalah abstraksi (hukum), nilai-nilai hukum, asasasas hukum, konsep-konsep hukum, dan norma-norma hukum yang dirumuskan secara umum dalam aturan-aturan hukum positif, kemudian dikonkritisasi (dijabarkan) dan diterapkan guna penyelesaian persoalan hukum konkrit yang dihadapi, begitu juga seterusnya secara bolak-balik dalam proses campuran. ${ }^{12}$

10 Ibid.

11 Peter Mahmud Marzuki, 2005, Penelitian Hukum, Jakarta: Kencana Prenada Media Group, hlm. 35.

12 Lihat, Yudha Bhakti Ardhiswastra, 2008, Penafsiran dan Konstruksi Hukum, Bandung: Alumni, hlm. 9; Bandingkan dengan Saut P. Panjaitan, 1998, Dasar-Dasar Ilmu Hukum: Asas, Pengertian, dan Sistematika, Palembang: Penerbit Universitas Sriwijaya, hlm. 158-159. 


\section{PEMBAHASAN}

\section{Peranan Laboratorium Forensik Keimigrasian Dalam Melakukan Pemeriksaan Paspor Palsu Kebangsaan Inggris Atas Nama Abbas Tauqeer}

\section{A. Peranan Laboratorium Forensik Keimigrasian ${ }^{13}$}

1. Peralatan Pemeriksaan yang dimiliki Laboratorium Forensik Keimigrasian

Laboratorium Forensik Keimigrasian memiliki beberapa peralatan yang digunakan untuk pemeriksaan dokumen keimigrasian, yaitu: ${ }^{14}$

a. Video Special Comparator VSC-4c;

b. ESDA (Electronic Detection Apparatus) ;

c. Stereo Microscope ;

d. UV floodlight;

e. Normal floodlight;

f. Digital SLR or High Prosumer Camera;

g. Tripod;

h. Scanner flatbed;

i. Flashlight and blacklight handheld kit;

j. Handheld Magnifier 10x kit;

k. Colour Laser Printer.

Pemeriksaan dokumen keimigrasian yang dilakukan di Laboratorium Forensik Keimigrasian memiliki tahapan sebagai berikut:

a. Peralatan yang digunakan dalam pemeriksaan awal

1) Kaca Pembesar dengan Lampu (Illuminated Magnifier)

Kaca pembesar dengan lampu digunakan untuk dapat melihat pengaman pada paspor dengan lebih detail, seperti cetakan latar belakang paspor (background printing), extra small printing, menemukan kesalahan cetakan, ataupun kerusakan kecil pada paspor yang tidak dapat dilihat dengan kasat mata.

2) Sinar atau lampu ultraviolet (UltraViolet Light)

Sinar atau lampu ultraviolet memiliki dua fungsi dalam pemeriksaan dokumen. Yang pertama adalah untuk melihat atau memeriksa apakah ada reaksi ultraviolet dari sebuah paspor atau visa. Sedangkan yang kedua adalah untuk menemukan watermark palsu, yang sering dapat terdeteksi dengan menggunakan lampu ultraviolet.

3) Alat penglihat 3M (3M Viewer)

\footnotetext{
13 Informasi diolah dari alur kerja Laboratorium Forensik Keimigrasian, Direktorat Intelijen Keimigrasian dalam melakukan pemeriksaan dokumen keimigrasian palsu.

Lihat juga, Prenardi Herdiyana, Op. cit., Badan Pengembangan Sumber Daya Manusia Hukum dan HAM RI, Akademi Imigrasi, hlm. 31-38.

14 Inventaris Instrumen Laboratorium Forensik Keimigrasian, Direktorat Intelijen Keimigrasian, Tahun 2015.
} 
Alat untuk melihat laminasi pengaman retroreflektif $3 \mathrm{M}$ (3M Retrorefelktif Security Laminate)

b. Peralatan yang digunakan dalam Pemeriksaan Lanjutan

1) Video Spectral Comparator 4c (VSC4c)

Alat pemeriksa dokumen yang memiliki beberapa fungsi seperti sinar ultraviolet, kaca pembesar yang bisa melakukan pembesaran beresolusi tinggi, sinar coaxial untuk melihat laminasi retro-reflektif, dan dapat pula digunakan untuk memeriksa apabila ada perubahan tinta pada dokumen. VSC4c ini terhubung dengan komputer, alat pemindai (scanner), dan printer sehingga hasil pemeriksaan dapat langsung disimpan di komputer atau dicetak.

2) Leica Discussion Stereomicroscope

Mikroskop yang mempunyai dua alat penglihat untuk digunakan oleh dua orang untuk meneliti objek yang sama secara bersamaan sehingga dapat saling mendiskusikan hasil penelitian tersebut.

3) Labino Light

Lampu sorot sinar ultraviolet untuk mendukung pengambilan foto dengan resolusi sinar ultraviolet tinggi.

c. Peralatan yang digunakan dalam pemeriksaan dilapangan (Securitech Inspection Kit)

Perlengkapan standar untuk melakukan pemeriksaan dokumen perjalanan pada saat dilapangan seperti pada saat pemeriksaan di atas pesawat, kapal laut.

\section{Prosedur Pemeriksaan Dokumen Keimigrasian Palsu15}

Pemeriksaan paspor palsu yang dilakukan oleh Laboratorium Forensik Keimigrasian pada umumnya merupakan permintaan dari Unit Pelaksana Teknis dari Kantor Imigrasi maupun Tempat Pemeriksaan Imigrasi atau instansi lainnya. Permintaan pemeriksaan ini meliputi pemeriksaan terhadap keaslian paspor, cap kedatangan dan keberangkatan serta visa.

Proses pemeriksaan dokumen perjalanan di Laboratorium Forensik Keimigrasian adalah sebagai berikut:

a. Observe, yaitu mengamati apa yang terlihat pada sebuah dokumen

Dokumen yang diterima oleh Laboratorium Forensik Keimigrasian akan diamati dengan menggunakan Video Spectral Comparator (VSC400) dan hasil pengamatan yang berupa gambar akan disimpan dalam komputer.

b. Infer, yaitu memperkirakan arti dari hasil pengamatan

Bila ditemukan suatu kejanggalan dalam hasil pengamatan sebelumnnya, akan diperkirakan apakah kejanggalan itu akibat dari adanya pemalsuan, akibat produksi yang kurang baik, cara penyimpanan yang tidak baik, atau hal-hal lain.

15 Haryono Agus Setiawan, 2010, Redefinisi Unit Laboratorium Forensik Keimigrasian: Fungsi dan Pemanfaatannya bagi Direktorat Jenderal Imigrasi, hlm 13. Lihat juga Anonim, Advanced Modul Pemeriksaan Dokumen, Direktorat Intelijen Keimigrasian, hlm. 94-99. 
c. Research, yaitu meneliti dengan lebih mendalam hasil dari perkiraan sebelumnnya.

Bagian dokumen yang memiliki kejanggalan tersebut akan diperiksa dengan lebih teliti.

d. Deduce, yaitu menyimpulkan hasil pemeriksaan.

Pada tahap ini disimpulkan dokumen tersebut asli atau palsu.

Perlu diketahui, tidak sedikit proses pemeriksaan dokumen keimigrasian palsu dilaksanakan dengan cara manual tanpa alat, hal ini bisa saja dilakukan akan tapi tidak maksimal, kemampuan indera manusia terbatas oleh karena itu untuk memaksimalkan potensi petugas imigrasi maka mereka perlu dibekali dengan alat. Kasus pemalsuan dan penggunaan dokumen keimigrasian palsu setiap saat terus terjadi di tengah-tengah pelayanan keimigrasian. Sarana laboratorium forensik dokumen dibutuhkan tidak hanya di pusat, tapi juga di daerah.

Pemeriksaan dokumen dilakukan berdasarkan level tingkatan pemeriksaan. Level tersebut dibagi berdasarkan fitur pengamannya, tempat, waktu, dan kewenangan pemeriksaan.

Berdasarkan fitur pengaman dokumen, pemeriksaan dikategorikan menjadi tiga tingkatan, yaitu: 16

a. Primer (Terbuka)

Yaitu, pada tingkatan ini tidak ada peralatan yang dibutuhkan untuk mengidentifikasi fitur pengaman. Misalnya, watermark dapat dilihat dengan mata telanjang dan sinar di belakang kertas.

b. Sekunder (Semi - Rahasia)

Peralatan dasar dibutuhkan untuk memverifikasi fitur pengaman. Misalnya, kaca pembesar untuk membaca garis microprint yang tercetak pada halaman.

c. Tersier (Tertutup)

Perlengkapan spesial (Special Equipment) diperlukan untuk mengotentikasi fitur pengaman dokumen tingkat ini. Misalnya, peralatan laboratorium yang diperlukan untuk mendeteksi perbedaan tinta dalam penyinaran inframerah, penyerapan tinta dan pewarnaan yang berbeda.

Berdasarkan tempat, waktu dan kewenangan pemeriksaan dokumen, terdapat tiga tingkatan pemeriksaan dokumen di mana terdapat keterseinambungan proses antar tingkat level. Misalnya tingkat pertama harus harus mengarahkan pemeriksaan ke tingkat berikutnya jika kecurigaan tidak dapat dikonfirmasi tanpa peralatan tambahan atau dalam rangka pemeriksaan ilmiah atau penyelidikan. Tingkatan tersebut, yaitu: ${ }^{17}$

a. Level 1 - Pendeteksian

16 Anonim, 2007, Pemeriksaan Paspor, Jakarta: Direktorat Lintas Batas dan Kerjasama Luar Negeri, Direktorat Jenderal Imigrasi, hlm. 47. Bandingkan dengan, Samsara, L., 2011. Inovasi Pelayanan Paspor di Kantor Imigrasi (Studi Tentang Peningkatan Kualitas Pelayanan Surat Perjalanan Republik Indonesia di Kantor Imigrasi Klas I Khusus Surabaya). Sumber, 6(111.169), pp.14-688.

17 Ibid. 
Padal level ini titik kontak pertama antar petugas dengan dokumen. Ditandai dengan gejala awal adanya ketidakberesan saat pertama kali terdeteksi, adanya keterbatasan atau tidak adanya peralatan standar, dan pendeteksian sangat bergantung pada pengetahuan dan keterampilan petugas pemeriksa. Level ini terdapat di Konter pemeriksaan petugas di TPI dan konter petugas Loket penerimaan persyaratan paspor atau pada loket wawancara permohonan paspor.

b. Level 2 - Penilaian

Pada level ini pemeriksaan dokumen dilakukan setingkat lebih tinggi. Di mana pada tahap ini ditubutuhkan lebih banyak keterampilan dan pengalaman. Peralatan dasar juga dibutuhkan untuk menilai dokumen dan petugas pada level ini akan membuat keputusan tentang apakah dokumen tersebut bermasalah atau tidak.

Jika pada level ini hasilnya masih tidak meyakinkan, atau pemeriksaan yang lebih rinci diperlukan lebih lanjut maka pemeriksaan dokumen dapat meningkat ke level tingkat selanjutnya.

c. Level 3 - Investigasi

Pada lavel ini diperlukan seorang petugas yang berkualitas dan berpengalaman yang dapat mengoperasikan peralatan laboratorium khusus pemeriksaan dokumen. Petugas Laboratorium memeriksa aspek fisika dan kimia yang ada pada dokumen yang mencurigakan. Penelitian dan hasil referensi silang dibuat untuk membantu dalam pengumpulan informasi intelijen. Pada tahap ini dihasilkan laporan tertulis yang digunakan dalam pembuktian di pengadilan. Dengan dukungan peralatan tersebut petugas mampu menyajikan bukti-bukti temuan dan member kesaksian di pengadilan jika diperlukan.

Sebagian besar kasus pemalsuan dan penggunaan dokumen palsu terjadi di tingkat UPT di daerah tempat pelayanan keimigrasian. Dan pada kenyataannya hanya sedikit sekali jumlah kasus pemalsuan dan penggunaan dokumen palsu yang diteruskan ke ranah pro justitia. Hal ini dikhawatirkan akan meniadakan efek jera bagi para pelaku tindak kejahatan tersebut serta melemahkan peran imigrasi yang memiliki perangkat (Penyidik Pegawai Negeri Sipil). ${ }^{18}$ Dengan tidak adanya alat bantu pertugas di lapangan tidak memiliki pola penanganan terstruktur dan sistematis terhadap kasus pemalsuan dan penggunaan dokumen palsu dan hanya berpedoman pada kebiasaan-kebiasan tidak ilmiah yang tidak bisa dipertanggungjawabkan.

\section{Pembuatan Laporan}

Setelah sebuah dokumen diperiksa dan didapat hasil pemeriksaannya, maka tahap selanjutnya adalah membuat laporan pemeriksaan. Laporan pemeriksaan ini memuat data-data sebagai berikut:

a. Informasi Penyerahan

\footnotetext{
18 Mohede, N., 2011. Sanksi Pidana terhadap Pelaku Tindak Pidana Keimigrasian. Jurnal Hukum Unsrat, 19(4).
} 
Yaitu, waktu penyerahan dokumen tersebut kepada Laboratorium Forensik Keimigrasian, dan nama serta instansi yang meminta pemeriksaan dokumen.

b. Permintaan Pemeriksaan

Yaitu, menerangkan pemeriksaan apa yang diminta, apakah pemeriksaan keaslian paspor, visa, cap kedatangan/ keberangkatan, dan sebagainya.

c. Deskripsi Dokumen

Yaitu, menjelaskan data-data dari dokumen tersebut, misalnya nomor paspor, nama pemegang paspor, tanggal pengeluaran paspor, dan lain-lain.

d. Metode Pemeriksaan

Yaitu menerangkan metode dan alat-alat pemeriksaan apa yang digunakan.

e. Pemeriksaan

Yaitu, memaparkan temuan-temuan yang didapat pada waktu dilakukan pemeriksaan.

f. Kesimpulan

Yaitu, hasil dari pemeriksaan tersebut.

\section{Pembuatan Produk Intelijen}

Peranan Laboratorium Forensik Keimigrasian sebagai fungsi intelijen dengan membuat document alert terkait dengan temuan dokumen palsu yang telah diperiksa kemudian dikaitkan dengan temuan lainnya ketika ada suatu hubungan yang berkaitan dengan tindak kejahatan.

\section{Pengarsipan}

Laporan pemeriksaan ini akan dibuat dalam rangkap dua untuk diberikan kepada pihak peminta pemeriksaan dan untuk disimpan sebagai arsip oleh Laboratorium Forensik Keimigrasian. Selain dalam bentuk kertas, arsip ini pun secara berkala disimpan dalam format compact disc.

\section{Pengamanan Dokumen Keimigrasian ${ }^{19}$}

Untuk mengukur keberhasilan sebuah negara dalam mengamankan dokumennya dari upaya pemalsuan maka dapat dilihat dari seberapa besar angka pemalsuan dokumen yang melibatkan dokumen tersebut. Ketika masih banyak dijumpai penggunaan dokumen palsu (paspor kebangsaan) di lapangan maka angka keberhasilan negara dalam mengamankan dokumennya dianggap kurang berhasil.

Selain menjalankan fungsinya sebagai lembaga untuk memeriksa keaslian sebuah dokumen, Laboratorium Forensik Keimigrasian juga memiliki peran untuk mengamankan dokumen keimigrasian. Fungsi tersebut tidak dapat dipisahkan karena memiliki keterkaitan satu sama lain. Pengamanan dokumen tidak hanya tergantung pada fitur pengaman canggih dari fisik dokumen itu sendiri, akan tetapi pengamanan dokumen dipengaruhi banyak faktor yang memengaruhi secara langsung dan tidak

19 Sigit Setiawan, Dokumen Sebagai Core Business Imigrasi, Direktorat Intelijen Keimigrasian, hlm. 57-60. 
langsung. Fitur pengaman pada dokumen hanya sebagian kecil dari upaya Negara untuk mengamankan dokumen.

Di dalam information security management terdapat pemahaman tentang teori pengamanan yang didalamnya terkait tiga hal, Confidentialy, Integrity dan Availability. Teori tersebut sangat menyadari bahwa faktor keamanan sangat terkait erat dengan sisi pelayanan yang menghendaki kecepatan dan efisiensi, serta dari sisi security itu sendiri yang tidak mentoleransi adanya celah keamanan atau pemalsuan dari unauthorised parties. Berikut unsur yang harus dipenuhi oleh Laboratorium Forensik Keimigrasian dalam melakukan pengamanan dokumen keimigrasian, yaitu:

a. Confidentialy (Kerahasiaan)

Dokumen dapat dikatakan aman apabila dokumen tersebut :

1) Memiliki fitur pengaman fisik yang sesuai dengan yang distandarkan (dalam hal dokumen adalah paspor maka dokumen harus memiliki fitur-fitur pengaman paspor merujuk pada standar ICAO 9303. Fitur pengaman tersebut dapat mencegah dan mempersulit dokumen untuk bisa dipalsukan. Jika dokumen dapat dipalsukan maka fitur pengaman tersebut akan memberikan informasi kepada petugas pemeriksa dokumen bahwa telah terjadi perubahan pada dokumen tersebut (tamper evidence). Contohnya fitur pengaman berupa Kinegram, Hologram dan Optical Variable Inks pada paspor yang mempersulit adanya perubahan atau pemalsuan;

2) Melalui proses distribusi, issuance atau proses penerbitan dokumen yang sesuai prosedur yang sudah ditetapkan dan terlindungi dari akses-akses yang tidak dikehendaki (illegal access) yang berpotensi pada kerugian, seperti pencurian, penghilangan, penggantian, penghapusan, perubahan dan pemalsuan data dan atau dokumen. Contohnya, manajemen pengelolaan blangko paspor yang diharapkan mampu menjaga dan mengamankan distribusi paspor dari Pusat ke daerah hingga diterbitkan kepada masyarakat.

b. Integrity (Integrasi)

Dokumen dapat dikatakan aman apabila dokumen tersebut:

1) Memiliki sistem pendukung yang terintegrasi terkoneksi satu dengan yang lain dalam rangka menjaga keamanan seluruh sistem dari upaya modifikasi oleh pihak-pihak yang tidak berhak dan tidak bertanggungjawab. Proses penerbitan paspor dilakukan dengan tahapan dari hulu hingga hilir. Selama proses tersebut sub sistem pendukung harus tangguh dari upaya sabotase dan pengaburan serta upaya perubahan yang tidak sah dan unprocedural sehingga mengakibatkan baik dokumen itu sendiri melalui sistem pendukungnya. Hal ini selaras dengan tugas yang diemban oleh Laboratorium Forensik Keimigrasian dalam mengamankan dokumen Paspor RI, karena setiap satu 
buah blangko paspor baik yang sudah terbit maupun belum, masih berlaku atau sudah expired adalah tetap milik negara dan negara bertanggung jawab terhadap pengamanannya. Contohnya adalah pencegahan penggunaan dokumen paspor hilang atau blangko paspor hilang yang dilakukan dengan mengandalkan pada konektivitas antar sistem, sehingga pasporpaspor palsu tersebut dapat terdeteksi apabila digunakan di Tempat Pemeriksaan Imigrasi;

2) Memiliki teknik pengaman data dan dokumen baik fisik maupun non-fisik dengan sistem maupun manual yang dapat mengukur dan mendeteksi akurasi kecocokan data baik fisik maupun digital. Contohnya, adalah apabila terdapat perubahan data pada paspor yang digunakan melalui pintu-pintu resmi maka sistem pemeriksaan akan dengan akurat memberitahu kepada petugas pemeriksa bahwa paspor tersebut tidak cocok datanya dengan pemegang karena memang telah dipalsukan.

c. Availability (Kemudahan)

Dokumen dapat dikatakan aman apabila dokumen tersebut:

1) Didukung oleh sistem pelayanan dan keamanan yang seimbang, dimana dua hal tersebut harus selalu berjalan beriringan sehingga tidak boleh salah satu dipisahkan dan tidak boleh saling melemahkan. Prinsip ini menekankan pentingnya faktor pelayanan bagi masyarakat. Prinsip ini memberikan kemudahan kepada masyarakat luas dalam hal pemeriksaan dokumen dan verifikasi otentikasi dokumen. Melalui peralatan otentikasi yang canggih dan aman maka pemeriksaan dokumen dapat dilakukan dengan lebih cepat, akurat dan aman. Prinsip ini menghendaki adanya ketersediaan sistem yang mampu mendukung aspekaspek kemudahan dalam bertransaksi, sehingga tidak terjadi mal-fungsi pada sistem pelayanan dan keamanan, serta terdapat kontrol yang ketat namun menghasilkan output pelayanan yang sangat efisien. Contohnya, adalah pada implementasi penggunaan E-Paspor atau Elektronik Paspor yang menggunakan electronic chip. E-paspor diterbitkan dalam rangka untuk memudahkan pemeriksaan penumpang di Tempat Pemeriksaan Imigrasi. Penumpang akan dimudahkan karena pemeriksaan sangat cepat, tanpa mekanisme berhadapan dengan petugas (melalui automatic gate) tapi pemeriksaan otomatis tersebut sudah dijamin akurat, aman dan valid. Pemeriksaan dijamin aman karena terjadi verifikasi antara paspor dan electronic chip yang dibaca oleh mesin serta otentikasi fitur biometric yang melekat pada diri pemegang paspor;

2) Memiliki sistem otentikasi yang dapat memastikan data, transaksi data dan komunikasi data di dalam sistem penerbitan 
paspor adalah genuine dan valid. Contohnya, verifikasi biometric antara pemegang paspor dan dokumen yang dimiliki dapat terjadi apabila sudah memiliki perangkat tersebut baik software maupun hardware, karena e-paspor tidak akan berdaya guna apabila tidak ada alat pembaca dokumen (decoder) tersebut di tempat pemeriksaan imigrasi.

\section{Peran Faktual Laboratorium Forensik Keimigrasian ${ }^{20}$}

Laboratorium Forensik Keimigrasian, Direktorat Intelijen Keimigrasian, menjalankan fungsi edukasi, yaitu dengan memberikan bimbingan teknis untuk meningkatkan kualitas sumber daya manusia bagi petugas imigrasi di Indonesia mengenai pendeteksian dan pemeriksaan dokumen keimigrasian. Berbagai pelatihan telah sering diberikan kepada petugas imigrasi Indonesia untuk memberikan kesadaran dan peringatan dini mengenai aktifitas jaringan para pelanggar, para pelaku kejahatan pemalsuan dokumen keimigrasian, sehingga dapat menambah pengetahuan dan keterampilan petugas imigrasi dalam melakukan pengumpulan, pengelolaan, dan penyajian data yang terkait dengan seluruh aktifitas penggunaan dan pemalsuan dokumen keimigrasian dalam sebuah produk intelijen.

Selain memberikan pengetahuan melalui pelatihan-pelatihan mengenai pemeriksaan dokumen keimigrasian palsu, Laboratorium Forensik Keimigrasian kerap diminta menjadi saksi ahli dipengadilan untuk memberikan keterangan secara ilmiah mengenai kasus pemalsuan dokumen keimigrasian.

\section{B. Teknik Pemeriksaan Laboratorium Forensik Dokumen Keimigrasian ${ }^{21}$}

\section{Pemeriksaan Dokumen ${ }^{22}$}

The American Society for Testing and Materials, International (ASTM) menerbitkan standar untuk banyak metode dan prosedur menggunakan Forensic Document Examiner (FDE). Standard Guide for Scope of Work of Forensic Document Examiners mengindikasikan 3 (tiga) komponen dalam pemeriksaan dokumen. Seorang pemeriksa dokumen membuat pengujian ilmiah, membandingkan, dan menganalisa dokumen dalam rangka untuk:

20 Selain itu, peranan laboratorium forensik keimigrasian adalah: (1) Fungsi Forensik, (2) Fungsi Edukasi, (3) Fungsi Intelijen, dan (4) Fungsi Penegakan Hukum. Sigit Setyawan, 2012, Implementasi Labfor di UPT Direktorat Jenderal Imigrasi, hlm. 9 Laboratorium Forensik Keimigrasian; Sigit Setiawan, 2012, Usulan Perawatan dan Pemeliharaan Peralatan Laboratorium Forensik Keimigrasian Direktorat Jenderal Imigrasi, Jakarta, hlm. 7.

${ }^{21}$ Sigit Setiawan, Op. cit., Direktorat Intelijen Keimigrasian, hlm. 43-50; Ada sembilan teknik pemeriksaan paspor palsu, yaitu: (1) memeriksa sampul depan paspor, (2) memeriksa setiap halaman paspor, (3) memeriksa penomoran, (4) data identitas pemegang paspor, (5) foto pemegang paspor, (6) plastik laminasi, (7) penjilidan, (8) memeriksa dengan sinar ultraviolet, dan (9) memperhatikan kualitas produksi.

${ }^{22}$ Lihat Putut Sukoco Nusantoro, Ilmu Forensik Keimigrasian, Bahan Ajar, Direktorat Intelijen Keimigrasian. 
a. menetapkan keaslian atau ketidakaslian, mengekspos pemalsuan, mengungkapkan perubahan, penambahan, atau penghapusan,

b. mengidentifikasi atau menghilangkan sumber ketikan atau kesan lainnya, tanda, atau bukti terkait, dan

c. membuat laporan atau kesaksian saat diperlukan untuk membantu pengguna jasa pemeriksa dokumen dalam memahami temuan si pemeriksa.

Pemeriksaan dokumen melibatkan alat bukti yang dapat dilihat, diuji, dan diukur. Dalam pemeriksaan dokumen diperlukan peralatan-peralatan yang membantu menguji keaslian dokumen tersebut dan menentukan fakta yang mungkin tidak terlihat tanpa bantuan dokumen ilmiah. Pemeriksaan terhadap dokumen palsu dilakukan melalui pendeteksian yang teratur dan studi yang sistematik untuk menjaga bukti dokumen yang diduga palsu tetap dalam kondisi yang baik. Metode pemeriksaan dokumen dilakukan salah satunya dengan melakukan perbandingan. Perbandingan dilakukan antara dokumen yang diduga palsu dengan dokumen otentik yang asli dengan mencari perbedaan yang terdapat pada kedua dokumen yang dibandingkan. ${ }^{23}$

\section{Makroskopik dan Mikroskopik}

Untuk mengidentifikasi sebuah dokumen dapat dilakukan penelitian makroskopik dan mikroskopik. Pemeriksaan maksroskopik merupakan pemeriksaan sebuah dokumen dengan penglihatan biasa menggunakan mata telanjang dengan bantuan cahaya yang dipantulkan/langsung (reflected light), dimiringkan (oblique light), dan cahaya yang diteruskan (transmitted light). Sedangkan pemeriksaan mikroskopik adalah pemeriksaan menggunakan mikroskop untuk objek yang tidak dapat dilihat dengan mata telanjang.

Jenis-jenis mikroskop yang biasa digunakan untuk pemeriksaan dokumen antara lain stereoscopic microscope, standard laboratory microscope, dan polarized light microscope (PLM). Stereoscopic microscope menggunakan pembesaran yang rendah dengan pencahayaan langsung, miring maupun pencahayaan yang diteruskan untuk menunjukkan objek yang relatif lebih besar seperti lukisan maupun dokumen yang lebih lebar. Standard laboratory microscope digunakan untuk melakukan tes mikro kimia dari sampel kertas maupun tinta. Tipe dari serat pada kertas dan pencampuran dari setiap tipe serat dapat ditentukan dengan teknik khusus. Polarized Light Microscope (PLM) biasanya digunakan pada laboratorium

23 Setiawan, A.W., 2016. Peran Pegawai Dalam Pelayanan Pembuatan Paspor di Kantor Imigrasi Samarinda. Jurnal Ilmu Pemerintahan Universitas Mulawarman, 4(1); Lihat UNODC, Staff Skill Requirements and Equipment Recomendations for Forensic Science Laboratories, United Nation, New York, 2011, hlm.101; UNODC, 2010, Forensic Service and Infrastructure: Criminal Justice Assessment Toolkit, New York: United Nation, hlm. 59. Bandingkan dengan UNODC, Guide For Development of Forensic Document Examination Capacity,United Nation,New York, 2012,hlm 15; Jeremy Travis, 1998, Forensic Laboratory: Handbook Facility, Planning, Design, Construction, and Moving, New York: US, Depatement of Justice, National Institute of Standards and Technology, hlm. 16. 
forensik yang lebih besar, biasanya menggunakan filter polarisasi cahaya (sebuah sifat cahaya yang bergerak menuju arah tertentu) untuk mengidentifikasi sebuah kandungan / zat. Contohnya seperti pada kasus lukisan minyak yang telah diragukan keasliannya dengan cara melihat adanya partikel yang telah diangkat.

\section{Pengujian Kertas}

Pemeriksaan terhadap dokumen Biasnya dilakukan dengan menguji jenis kertasnya, tinta dan juga warna dokumen tersebut. Pengujian terhadap kertas terbagi menjadi dua cara, yaitu tes non-destruktif dan tes destruktif. Tes non-destruktif dilakukan dengan melihat warna, bentuk, ukuran, ketebalan setiap lembar kertas, watermarks (tanda air), pola atau tanda yang ada pada kertas yang diproduksi, tampilan permukaan kertas (berwarna atau belang), halus atau kakunya kertas saat diraba, dan bunyi yang dihasilkan saat kertas tersebut digerakkan. Penggunaan fluorescence atau sinar ultraviolet dapat juga dilakukan untuk memeriksa sebuah kertas tanpa merusak kertas tersebut. Tes destruktif dilakukan dengan menghancurkan sedikit sobekan kertas menggunakan air, atau bila diperlukan menggunakan dilute acid (asam cair) atau alkali sehingga menjadi campuran pulp (bubur) yang selanjutnya dapat diperiksa serat-serat yang terkandung di dalamnya menggunakan mikroskop.

\section{Fotografi Forensik}

Terdapat 3 (tiga) fungsi fotografi dalam pemeriksaan dokumen keimigrasian, yaitu (1) untuk membuat catatan permanen dari sebuah dokumen sebelum dokumen tersebut rusak saat pemeriksaan, (2) untuk mendeteksi fitur-fitur tertentu yang tidak terlihat secara kasat mata, dan (3) untuk menyiapkan materi dimana diperlukan adanya peragaan di pengadilan.

Sebuah foto yang akan dijadikan sebagai alat peraga atau bukti di pengadilan haruslah dipersiapkan dengan baik dengan menampilkan informasi-informasi penting yang dapat dilihat dan mampu dijelaskan dengan sebuah gambar. Untuk menghasilkan hasil foto yang bagus dan layak digunakan sebagai pembuktian di pengadilan, diperlukan peralatan yang layak sebagai syarat mutlak dan keahlian fotografi dalam menggunakan kepiawaiannya untuk masalah yang ditimbulkan oleh berbagai dokumen yang berbeda. ${ }^{24}$

Adapun fotografi forensik yang dilakukan oleh Laboratorium Forensik Keimigrasian dalam melakukan pemeriksaan dokumen keimigrasian palsu adalah melalui fotografi ultraviolet dan infrared. Fotografi tidak hanya mampu merekam benda yang dapat terlihat, tapi juga merekam benda yang tidak dapat dilihat secara kasat mata. Penerangan dengan sinar infrared dan ultraviolet dapat digunakan untuk mendokumentasikan sebuah gambar yang tidak terlihat. Emulsi fotografi dapat dibuat sensitif terhadap radiasi

24 Dewansyah, B., 2015. Perkembangan Politik Hukum dan Kebutuhan Hukum Keimigrasian Indonesia: Menjawab Sebagian, Melupakan Selebihnya. Hasanuddin Law Review, 1(2), pp.140-162. 
ultraviolet dan infrared. Untuk menghasilkan foto dengan kedua radiasi cahaya ini digunakan teknik khusus. Fotografi ultraviolet dapat dilakukan menggunakan filter khusus yang hanya menerima sinar ultraviolet. Teknik fotografi lain yang menggunakan sinar ultraviolet adalah fotografi ultraviolet fluorescence dimana dokumen diterangi dengan sinar ultraviolet dan kamera berfilter yang menyerap sinar ultraviolet. Meskipun demikian, hanya visible fluorescence yang dapat dilihat oleh film pada kamera. Pada fotografi infrared diperlukan filter khusus yang dapat menghalangi cahaya sinar yang tidak diinginkan dan film khusus berkecepatan tinggi yang peka terhadap radiasi infrared, serta dilakukan pada ruangan yang sangat gelap.

\section{Pemeriksaan Forensik Pemalsuan Paspor Kebangsaan Inggris Atas Nama Abbas Tauqeer \\ 1. Kasus Posisi}

Abbas tauqeer lahir pada tanggal 16 Agustus 1978 di Sheikhpura, Bihar, India. Ia mengaku sebagai warga Negara Inggris. Hal ini dibuktikan dengan adanya Paspor Inggris dengan Nomor Paspor: 308171806 yang diterbitkan pada tanggal 20 September 2007 dan berlaku sampai 20 September 2017. Ia masuk ke Indonesia melalui Bandar Udara Internasional Soekarno Hatta, pada tanggal 29 Juli 2015 dengan menggunakan Bebas Visa Kunjungan Wisata yang berlaku sampai tanggal 17 Agustus 2015.

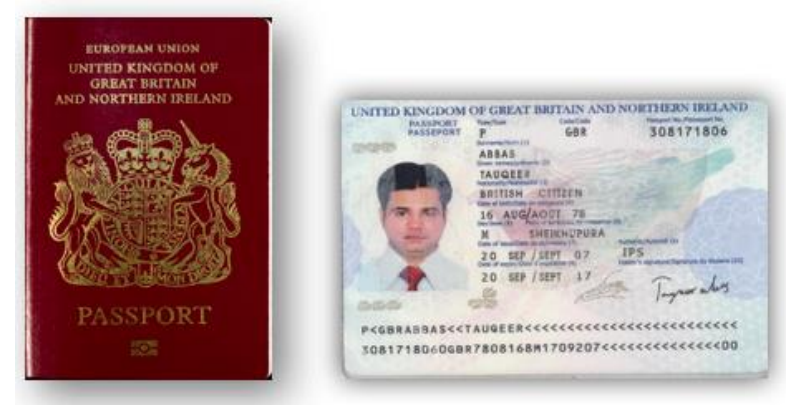

Gambar 1. Paspor Inggris (Palsu) Atas Nama Abbas Tauqeer

Pada hari Sabtu, tanggal 01 Agustus 2015, pukul 20.00 WITA, Abbas Tauqeer diamankan oleh Petugas Imigrasi pada Kantor Imigrasi Kelas I Khusus Ngurah Rai. Pada saat ditangkap, ia sedang tidur di bandara karena tidak memiliki uang untuk tinggal di hotel. Petugas meyakini bahwa Paspor Inggris yang ia miliki tersebut adalah palsu. Dalam pemeriksaan, ia tidak mengakui memiliki paspor Pakistan. Namun, ia hanya mengakui memiliki National Indentity Card yang dikeluarkan oleh Pemerintah Pakistan.

\section{Modus Pemalsuan}

Abbas Tauqeer mendapatkan Paspor Inggris palsu di Malaysia. Pemalsuan dilakukan pada halaman biodata paspor dengan cara mengganti identitas pemegang asli dan merusak Radio Frequency Identification (RFId) berupa Chip yang terdapat di belakang halaman paspor. Namun, Ghost Image 
telah diganti sesuai dengan foto Impostor (Abbas Tauqeer). Ini tentu sedikit menyulitkan pemeriksa, mengingat biasanya Ghost Image cukup sulit untuk diubah.

Selalu ada modus operandi di setiap kejahatan. Begitu pula yang dialami oleh Abbas Tauqeer. Ia mencoba menyelundupkan dirinya sendiri ke Indonesia agar dapat masuk ke negara tujuannya, yaitu Australia. Ia mencoba aksi ini secara perorangan dengan cara berangkat dari Malaysia, lalu mendarat ke Bandar Udara Internasional Soekarno Hatta (Indonesia) menggunakan Bebas Visa Kunjungan Wisata (BVKW). Setelah berhasil masuk dan tinggal beberapa hari di Indonesia, ia kemudian ditangkap di Bandar Udara Internasional Ngurah Rai oleh Petugas Imigrasi Kantor Imigrasi Kelas I Khusus Ngurah Rai. Setelah dilakukan pemeriksaan, diketahui bahwa memang tujuan awalnya memang ke Australia melalui Indonesia dengan menggunakan Paspor Inggris palsu.

\section{Analisa Kasus}

Pada halaman biodata paspor terdapat kerusakan berupa sobekan yang dapat dilihat dengan kaca pembesar. Sobekan tersebut mengindikasikan bahwa halaman paspor asli telah diubah dengan cara menempelkan halaman biodata

palsu.
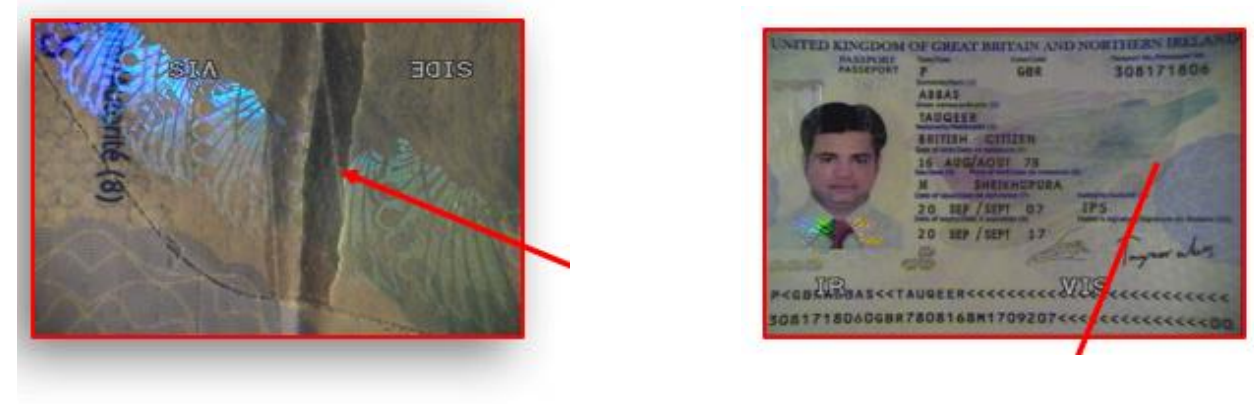

Gambar 2. Kerusakan pada Halaman Biodata Paspor

Jenis huruf yang tertera dalam halaman biodata paspor tidak konsisten (berbeda). Hal tersebut dapat dilihat dari jenis huruf " $M$ " dalam jenis kelamin pemegang paspor dan huruf "M" dalam MRZ. 


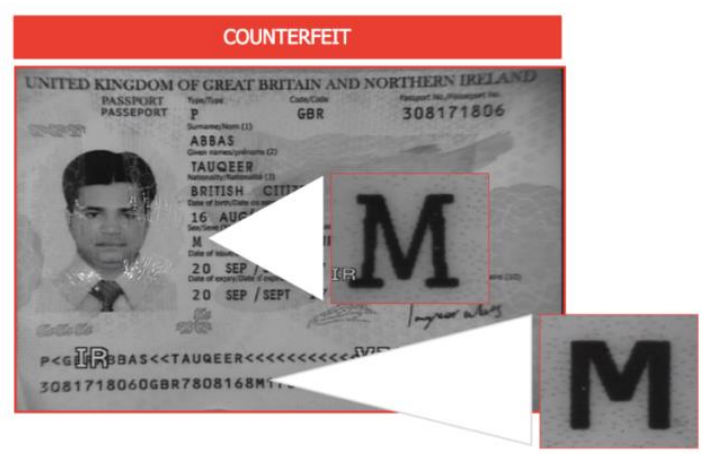

Gambar 3. Perbedaan Jenis Huruf pada Halaman Biodata Paspor

Pada bagian foto dan biodata telah diganti dengan cara mencetak kembali di halaman biodata asli. Terlihat letak huruf yang tidak presisi dan foto yang tidak kontras dengan bagian biodata lainnya.

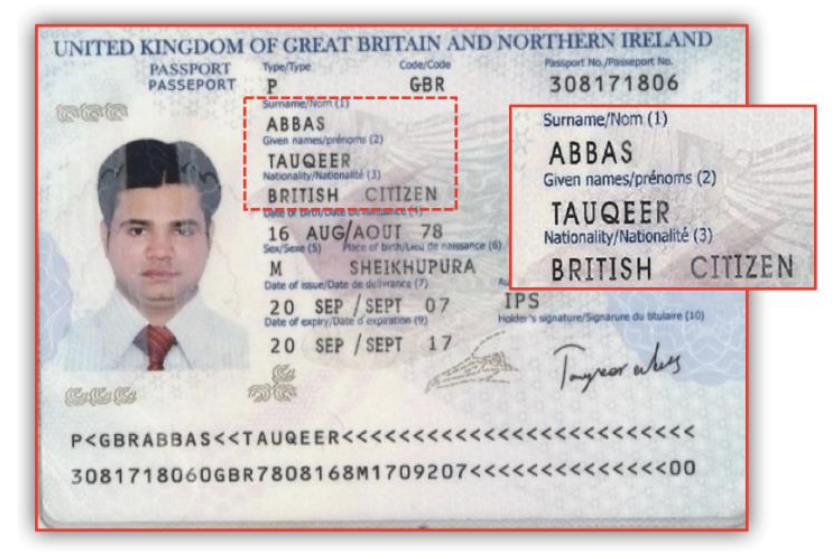

Gambar 4. Foto dan Biodata Telah Diganti

Pada saat dilakukan pengecekan menggunakan alat "The Automatic Document Reader", maka chip tersebut tidak dapat terbaca. Ada perbedaan yang sangat mendasar antara foto dan biodata yang tertera dalam halaman biodata paspor dengan biodata pemegang paspor asli. 


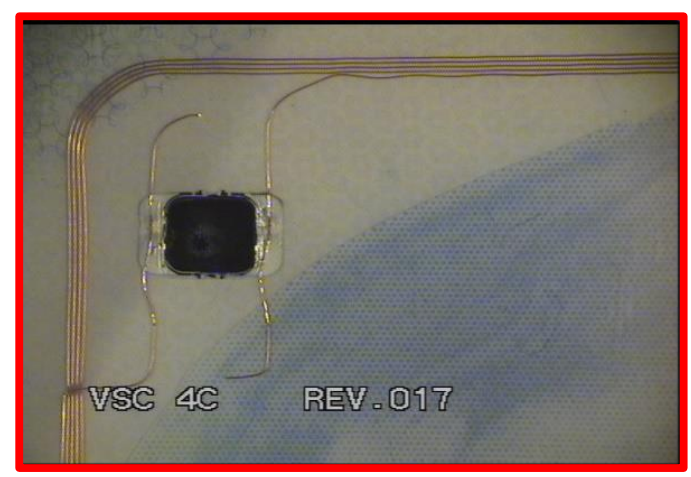

Gambar 5. Chip Paspor Rusak

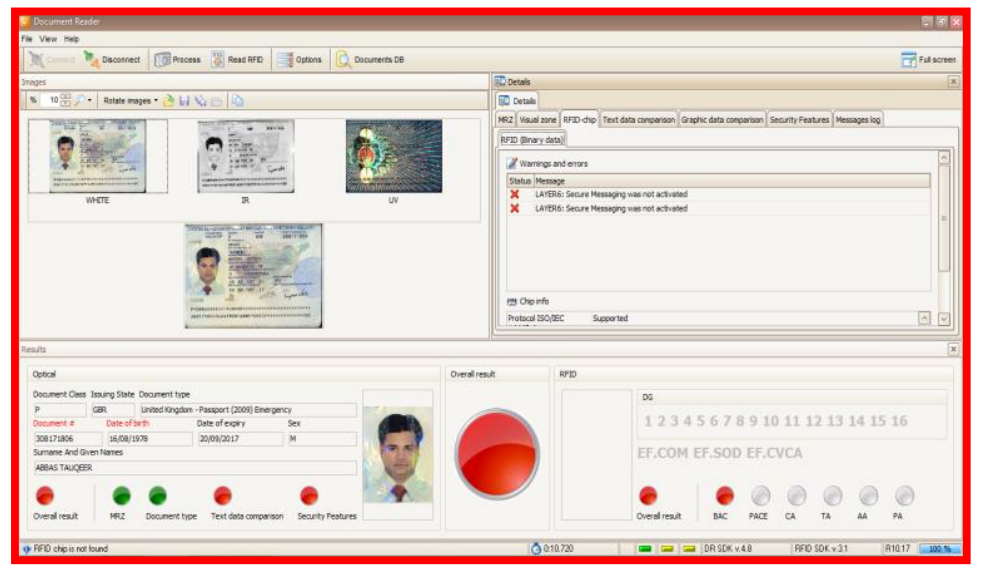

Gambar 6. Chip Tidak Terbaca pada "The Automatic Document Reader"

Kemudian pada saat dilakukan pembesaran, terlihat benang jahitan pada paspor sudah pernah dibuka. Diduga paspor tersebut telah dibongkar untuk dilakukan pemalsuan di beberapa halaman.

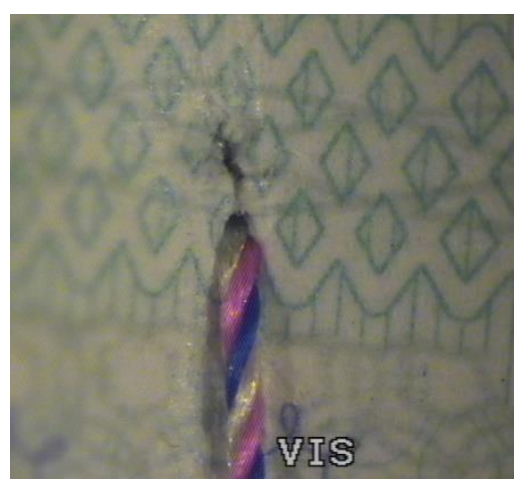

Gambar 7. Benang Jahitan Sudah Pernah Dibuka 


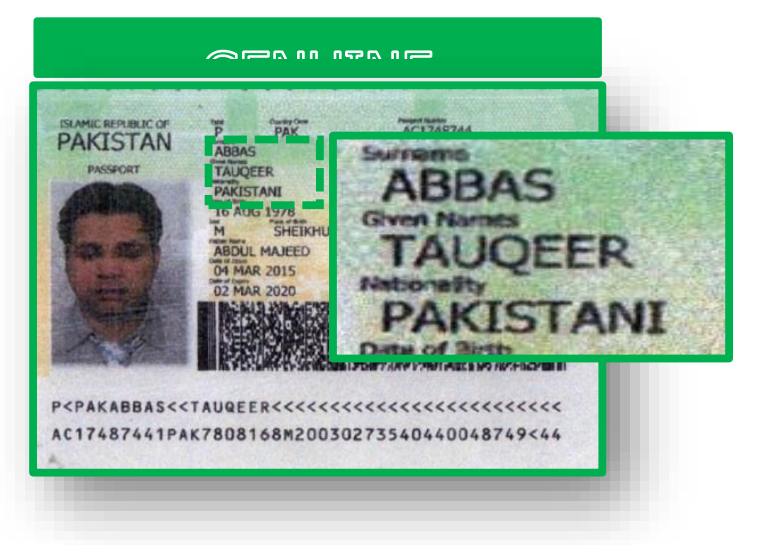

Gambar 8. Paspor Paksistan (Asli) dari Abbas Tauqeer

Setelah dilakukan proses pemeriksaan secara mendalam, diketahui bahwa yang bersangkutan adalah pemegang paspor Pakistan. Tingkat pemalsuan yang dilakukan dalam Paspor Inggris tersebut dapat dikategorikan profesional, karena data yang terdapat dalam RFId tidak terbaca sama sekali, sehingga data tidak tampil di Automatic Document Reader. Proses pemeriksaan dilakukan di Laboratorium Forensik Keimigrasian, Direktorat Intelijen Keimigrasian dan membutuhkan waktu dua hari. Peralatan yang digunakan dalam proses pemeriksaan menggunakan peranti Video Spectral Comparator (VSC), Automatic Document Reader, Mikroskop, Scanner, Komputer, dan Software berupa Edison.net dan Kissing.

\section{Tantangan Yang Dihadapi Laboratorium Forensik Keimigrasian Dalam Melakukan Pemeriksaan Paspor Palsu Kebangsaan Inggris Atas Nama Abbas Tauqeer}

\section{A. Tantangan Internal 25}

\section{Minimnya Sumber Daya Manusia}

Saat ini jumlah petugas imigrasi yang bertugas di Laboratorium Forensik Keimigrasian hanya 2 (dua) orang, yang terdiri dari 1 (satu) Kepala Seksi dan 1 (satu) orang Pejabat Imigrasi. Kuantitas ini tentu sangat tidak ideal mengingat jumlah permohonan pemeriksaan paspor cukup meningkat tajam setiap tahunnya. Tahun 2014 jumlah permohonan yang masuk berjumlah 6 (enam) kasus dan Tahun 2015 berjumlah 9 (sembilan) kasus. Hal inilah yang harus diantisipasi secara serius. Dengan jumlah petugas yang sedikit, maka akan mempengaruhi kinerja dari Laboratorium Forensik Keimigrasian ke depannya. Sebagai contoh untuk pemeriksaan dokumen palsu dibutuhkan proses yang panjang dari awal pemeriksaan hingga pelaporan dan pengarsipan tidak bisa dilakukan hanya satu petugas, kondisi ini dapat menghambat kinerja Laboratorium Forensik Keimigrasian dalam

25 Hasil Wawancara dengan Kepala Seksi Laboratorium Forensik Keimigrasian, Direktorat Intelijen Keimigrasian pada hari Rabu (23/03/2016), pukul 15.09 WIB. 
memberikan pelayanan yang tepat waktu dan terukur dalam penyajian produk intelijen keimigrasian

Selain itu juga perlu dilakukan peningkatan kualitas kompetensi petugas imigrasi yang menaruh minat terhadap bidang forensik keimigrasian. Harus diakui, forensik keimigrasian bukanlah kajian yang menarik. Namun di balik hal tersebut, hanya dengan metode forensik keimigrasian lah maka kita dapat mengungkap kasus-kasus pemalsuan paspor setiap warga negara. Mengingat telah diberlakukannya kebijakan Bebas Visa Kunjungan dan Masyarakat Ekonomi ASEAN (MEA), maka potensi pemalsuan paspor akan meningkat tajam. Sehingga penambahan kuanitas dan peningkatan kualitas petugas Imigrasi di Laboratorium Forensik Keimigrasian menjadi suatu keniscayaan.

\section{Sarana dan Prasarana Belum Representatif}

Sebagai pusatnya pemeriksaan paspor di Indonesia, Laboratorium Forensik Keimigrasian perlu didukung dengan peningkatan sarana dan prasarananya. Saat ini Laboratorium Forensik Keimigrasian menempati ruangan yang belum cukup untuk memenuhi standar sebuah laboratorium forensik. Peralatan instrumen Laboratorium Forensik Keimigrasian pun perlu ditingkatkan kualitasnya. Pesatnya perkembangan teknologi sekarang ini berujung pada meningkatnya pula teknik pemalsuan dokumen keimigrasian palsu. Apabila ini tidak diantisipasi, maka Laboratorium Forensik Keimigrasian akan tertinggal jauh dengan modus operansi pelaku yang semakin imajinatif. Sebagai contoh, Laboratorium Forensik Keimigrasian saat ini hanya memiliki mikroskop dengan perbesaran 60 kali. Padahal sesuai dengan kebutuhaan saat ini, mikroskop yang dibutuhkan adalah dengan 200 kali perbesaran. Selain itu, peranti yang masih dirasa kurang adalah alat untuk mendeteksi Impostor. Sejatinya alat ini sangat diperlukan, karena tren impostor semakin meningkat tiap tahunnya.

\section{Belum ada Standard Operational Procedure (SOP) Laboratorium Forensik Keimigrasian}

Selama ini pola kerja pemeriksaan paspor palsu di Laboratorium Forensik Keimigrasian belum terpadu. Pelaksanaan tugas hanya berdasarkan sistem kerja normal tanpa diikat oleh suatu pedoman kerja tertentu. Misalnya, berapa hari maksimal pemeriksaan dilakukan, apa tahapan yang harus dilakukan setelah proses pemeriksaan, apa hubungan kerja Laboratorium Forensik Keimigrasian dengan seksi lainnya, serta bagaimana format laporan kegiatan yang harus disajikan. Persoalan semacam ini akan menimbulkan kerancuan. Kini, sudah waktunya untuk menyusun sebuah pedoman kerja guna menjelaskan proses, pola kerja, dan produk yang dihasilkan dari sebuah kegiatan Laboratorium Forensik Keimigrasian.

\section{B. Tantangan Eksternal ${ }^{26}$}

26 Hasil Wawancara dengan Kepala Seksi Laboratorium Forensik Keimigrasian, Direktorat Intelijen Keimigrasian pada hari Rabu (23/03/2016), pukul 15.15 WIB. 
Tantangan eksternal yang dihadapi, yaitu masih minimnya kepedulan Petugas Imigrasi di lapangan untuk mengajukan permohonan pemeriksaan paspor palsu ke Laboratorium Forensik Keimigrasian, Direktorat Intelijen Keimigrasian. Petugas masih menganggap urgensi pemeriksaan forensik hanya sebatas verifikasi ilmiah, sehingga apabila masih dapat diselesaikan di tempat maka tidak perlu diajukan permohonan ke Laboratorium Forensik Keimigrasian. Paradigma ini sudah seharusnya dihilangkan. Bagaimana pun juga, kehadiran Laboratorium Forensik Keimigrasian tidak dapat diragukan sebagai lembaga sah dan formal yang diberikan amanat oleh pemerintah untuk menguji kebenaran terhadap kasus pemalsuan paspor di Indonesia.

\section{PENUTUP}

\section{A. Kesimpulan}

Berdasarkan uraian di atas, maka kesimpulannya sebagai berikut:

1. Peranan Laboratorium Forensik Keimigrasian Direktorat Intelijen Keimigrasian dalam melakukan pemeriksaan paspor palsu kebangsaan Inggris atas nama Abbas Tauqeer:

a. Tahapan yang dilakukan:

1) Pemeriksaan dokumen keimigrasian palsu;

2) Pembuatan laporan;

3) Pembuatan produk intelijen;

4) Pengarsipan.

5) Pengamanan Dokumen Keimigrasian

b. Teknik Pemeriksaan Laboratorium Forensik Dokumen Keimigrasian

1) Pemeriksaan Dokumen

2) Makroskopik dan Mikroskopik

3) Pengujian Kertas

4) Fotografi Forensik

c. Analisa Kasus:

1) Kerusakan pada halaman biodata paspor;

2) Perbedaan jenis huruf pada halaman biodata paspor;

3) Foto dan biodata telah diganti;

4) Chip paspor rusak;

5) Chip tidak terbaca pada Automatic Document Reader.

2. Tantangan yang dihadapi Laboratorium Forensik Keimigrasian Direktorat Intelijen Keimigrasian dalam melakukan pemeriksaan paspor palsu kebangsaan Inggris atas nama Abbas Tauqeer:

a. Tantangan Internal:

1) Minimnya sumber daya manusia;

2) Sarana dan prasarana belum representatif;

3) Belum adanya Standard Operational Procedure (SOP) Laboratorium Forensik Keimigrasian.

b. Tantangan Eksternal 
1) Minimnya kepedulian petugas Imigrasi.

\section{B. Saran}

Dalam rangka meningkatkan peranan laboratorium forensik keimigrasian yang tepat sasaran, maka saran yang dapat disampaikan adalah perlu dilakukan pembenahan dalam hal:

1. Perlu adanya penguatan fungsi manajemen pada Laboratorium Forensik Keimigrasian dengan pengembangan ruangan yang representatif, penambahan jumlah petugas, dan peralatan laboratorium sesuai dengan perkembangan teknologi untuk meningkatkan kinerja laboratorium yang efektif;

2. Perlu segera dibentuk Standard Operational Procedure (SOP) sebagai pedoman pelaksanaan tugas dan fungsi Laboratorium Forensik Keimigrasian;

3. Perlu dikeluarkannya Surat Edaran Direktur Jenderal Imigrasi yang ditujukan kepada setiap Kepala UPT Imigrasi agar setiap kasus yang terindikasi adanya pemalsuan dokumen perjalanan dan/atau keimigrasian dapat dilakukan uji keabsahan di Laboratorium Forensik Keimigrasian;

4. Perlu segera direalisasikan pengadaan alat-alat forensik di Tempat Pemeriksaan Imigrasi besar yang bertujuan meminimalisir potensi terjadinya penyalahgunaan dokumen perjalanan dan keimigrasian palsu di Indonesia;

5. Perlu dilakukan integrasi alat-alat forensik yang terdapat di Tempat Pemeriksaan Imigrasi ke Laboratorium Forensik Keimigrasian untuk memudahkan pemeriksaan forensik yang didasarkan pada tingkat kesulitan pemalsuan;

6. Perlu dilakukan peningkatan sumber data forensik (database), seperti fitur pengaman Paspor RI, Visa RI, Cap Tanda Masuk dan/atau Tanda Keluar, serta dokumen keimigrasian negara lain.

\section{DAFTAR PUSTAKA}

\section{Buku}

Anonim, Advanced Modul Pemeriksaan Dokumen. Direktorat Intelijen Keimigrasian

Anonim. Pemeriksaan Dokumen Modern. Direktorat Intelijen Keimigrasian

Anonim. 2007. Pemeriksaan Paspor. Jakarta: Direktorat Lintas Batas dan Kerjasama Luar Negeri. Direktorat Jenderal Imigrasi

Chotib. Migrasi: Kajian Kependudukan dan Ketenagakerjaan. Program Pascasarjana Universitas Indonesia

Jeremy Travis. 1998. Forensic Laboratory: Handbook Facility, Planning, Design, Construction, and Moving. New York: US. Depatement of Justice. National Institute of Standards and Technology. 
Jonny Ibrahim, 2006, Teori dan Metode Penelitian Hukum Normatif, Malang: Bayumedia

M. Arif Nasution. 1999. Globalisasi dan Migrasi Antar Negara. Bandung: Penerbit Alumni

M. Iman Santoso, Perpektif 2007, Imigrasi dalam United Nation Convention Against Transnational Organized Crime, Cet-1, Jakarta: Perum Percetakan Negara RI

M. Iman Santoso, 2014, Perspektif Imigrasi dalam Migrasi Manusia, Bandung: Pustaka Reka Cipta

Peter Mahmud Marzuki, 2005, Penelitian Hukum, Jakarta: Kencana Prenada Media Group

Soerjono Soekanto, 2010, Pengantar Penelitian Hukum, Penerbit Universitas Indonesia,

Sigit Setiawan, Dokumen Sebagai Core Business Imigrasi, Direktorat Intelijen Keimigrasian

UNODC. 2010. Forensic Service and Infrastructure: Criminal Justice Assessment Toolkit. New York: United Nation.

. 2010. Guide for The Development of Forensic Document Examination Capacity. New York: United Nation.

. 2011. Staff Skill Requirements and Equipment Recommendations for Forensic Science Laboratory. New York: United Nation.

\section{Jurnal}

Syahrin, M.A., 2017. The Implementation of Non-Refoulement Principle to the Asylum Seekers and Refugees in Indonesia. Sriwijaya Law

Review, 1(2), pp.168-178.

Mohede, N., 2011. Sanksi Pidana terhadap Pelaku Tindak Pidana Keimigrasian. Jurnal Hukum Unsrat, 19(4).

Setiawan, A.W., 2016. Peran Pegawai Dalam Pelayanan Pembuatan Paspor di Kantor Imigrasi Samarinda. Jurnal Ilmu Pemerintahan Universitas Mulawarman, 4(1).

Dewansyah, B., 2015. Perkembangan Politik Hukum dan Kebutuhan Hukum Keimigrasian Indonesia: Menjawab Sebagian, Melupakan Selebihnya. Hasanuddin Law Review, 1(2), pp.140-162.

Fernando, S., 2014. Politik Hukum Pemerintah (Direktorat Jenderal Imigrasi) Dalam Menanggulangi Masalah Penyelundupan Manusia. Kumpulan Jurnal Mahasiswa Fakultas Hukum, 1(1).

Samsara, L., 2011. Inovasi Pelayanan Paspor di Kantor Imigrasi (Studi Tentang Peningkatan Kualitas Pelayanan Surat Perjalanan Republik 
Indonesia di Kantor Imigrasi Klas I Khusus Surabaya). Sumber, 6(111.169), pp.14-688.

\section{Makalah}

Haryono Agus Setiawan. 2010. Redefinisi Laboratorium Forensik Keimigrasian: Fungsi dan Pemanfaatannya bagi Direktorat Jenderal Imigrasi. Jakarta

Sigit Setyawan. 2012. Implementasi Labfor di UPT Direktorat Jenderal Imigrasi. Laboratorium Forensik Keimigrasian.

2012. Pemeriksaan Dokumen Palsu dan Impostor. Laboratorium Forensik Keimigrasian.

2012. Usulan Perawatan dan Pemeliharaan Peralatan Laboratorium Forensik Keimigrasian Direktorat Jenderal Imigrasi. Jakarta.

\section{Majalah}

M. Alvi Syahrin, Reorientasi Fungsi Imigrasi Indonesia: Kembalikan ke Fitrah Penjaga Gerbang Negara, Majalah Bhumi Pura, September 2015, Jakarta: Direktorat Jenderal Imigrasi

M. Alvi Syahrin, Imigran Ilegal, Migrasi atau Ekspansi?, Majalah Check Point, Edisi 3, Oktober 2015, Jakarta: Akademi Imigrasi

M. Alvi Syahrin, Hak Asasi Bermigrasi, Majalah Bhumi Pura, November 2015, Jakarta: Direktorat Jenderal Imigrasi

Sigit Setiawan, Dokumen Core Business Imigrasi,: Menyiapkan Senjata Bagi Penjaga Gerbang Negara, Majalah Bhumi Pura, September 2015, Jakarta: Direktorat Jenderal Imigrasi, hlm. 30-32

\section{Bahan Bacaan Lainnya}

Berita Acara Interogasi Tauqeer Abbas, dilaksanakan pada hari Minggu (02/08/2015), pukul 14.00 WITA, bertempat di Kantor Imigrasi Klas I Khusus Ngurah Rai

Prenardi Herdiyana, 2013, Peranan Laboratorium Forensik Keimigrasian Direktorat Jenderal Imigrasi Dalam Pemeriksaan Dokumen Keimigrasian Palsu, Kertas Kerja Perorangan, Badan Pengembangan Sumber Daya Manusia Hukum dan HAM RI, Akademi Imigrasi

Putut Sukoco Nusantoro, Ilmu Forensik Keimigrasian, Bahan Ajar, Direktorat Intelijen Keimigrasian

\section{Peraturan Perundang-Undangan}

Indonesia. Undang-Undang tentang Keimigrasian. UU No. 6 Tahun 2011. LN Tahun 2011 Nomor 52. 
Indonesia. Peraturan Pemerintah tentang Peraturan Pelaksanaan UU No. 6 Tahun 2011 tentang Keimigrasian. PP No. 31 Tahun 2013. LN Tahun 2013 Nomor 68.

Peraturan Menteri Hukum dan Hak Asasi Manusia Republik Indonesia Nomor 29 Tahun 2015 Tentang Organisasi Tata Kerja Kementerian Hukum dan Hak Asasi Manusia Republik Indonesia.

\section{Internet}

M. Alvi Syahrin, Imigran Ilegal dan HAM Universal, diakses dari http://muhammadalvisyahrin.blogspot.co.id/2014/11/imigran-ilegaldan-ham-universal.html, diakses pada hari Sabtu (30/01/2016), pukul 15.54 WIB 